\title{
Regulation of Chk2 gene expression in lymphoid malignancies: involvement of epigenetic mechanisms in Hodgkin's lymphoma cell lines
}

N Kato ${ }^{1}$, H Fujimoto ${ }^{1}$, A Yoda ${ }^{1}$, I Oishi ${ }^{1}$, N Matsumura ${ }^{1}$, $\mathrm{T} \mathrm{Kondo}^{2}$, J Tsukada ${ }^{3}$, Y Tanaka ${ }^{3}$, M Imamura $^{4}$ and $\mathrm{Y}$ Minami $^{*, 1}$

1 Department of Genome Sciences, Faculty of Medical Sciences, Graduate School of Medicine, Kobe University, 7-5-1, Kusunoki-cho, Chuo-ku, Kobe 650-0017, Japan

2 Department of Gastroenterology and Hematology, Hokkaido University, Graduate School of Medicine, Kita 15 Nishi 7, Kita-ku, Sapporo, Hokkaido 060-8638, Japan

${ }^{3}$ First Department of Internal Medicine, University of Occupational and Environmental Health, School of Medicine, Kitakyushu 807-8555, Japan

${ }^{4}$ Department of Hematology and Oncology, Hokkaido University, Graduate School of Medicine, Kita 15 Nishi 7, Kita-ku, Sapporo, Hokkaido 060-8638, Japan

* Corresponding author: Y Minami, Department of Genome Sciences, Faculty of Medical Sciences, Graduate School of Medicine, Kobe University, 7-5-1, Kusunoki-cho, Chuo-ku, Kobe 650-0017, Japan. Tel: + 81-78-382-5560; Fax: +81-78-382-5579; E-mail: minami@kobe-u.ac.jp

Received 16.2.04; revised 4.3.04; accepted 13.4.04; published online 21.5.04 Edited by $\mathrm{H}$ Ichijo

\section{Abstract}

The tumor suppressor Chk2 kinase plays crucial roles in regulating cell-cycle checkpoints and apoptosis following DNA damage. We investigated the expression levels of the genes encoding Chk2 and several cell-cycle regulators in nine cell lines from lymphoid malignancies, including three Hodgkin's lymphoma (HL) lines. We found that all $\mathrm{HL}$ cell lines exhibited a drastic reduction in Chk2 expression without any apparent mutation of the Chk2 gene. However, expression of Chk2 in HL cells was restored following treatment with the histone deacetylase inhibitors trichostatin A (TsA) and sodium butyrate (SB), or with the DNA methyltransferase inhibitor 5-aza-2'-deoxycytidine (5Aza-dC). Chromatin-immunoprecipitation (Chip) assays revealed that treatment of $\mathrm{HL}$ cells with TsA, SB or 5Aza-dC resulted in increased levels of acetylated histones $\mathrm{H} 3$ and $\mathrm{H} 4$, and decreased levels of dimethylated $\mathrm{H} 3$ lysine 9 at the Chk2 promoter. These results indicate that expression of the Chk2 gene is downregulated in $\mathrm{HL}$ cells via epigenetic mechanisms.

Cell Death and Differentiation (2004) 11, S153-S161.

doi:10.1038/sj.cdd. 4401461

Published online 21 May 2004

Keywords: cell-cycle checkpoint; Chk2 gene; DNA methylation; epigenetic mechanism; histone modification; Hodgkin's lymphoma (HL); lymphoid malignancy; tumor suppressor

Abbreviations: ATM, ataxia-telangiectasia-mutated; $5 \mathrm{Az}-\mathrm{dC}, 5-$ aza-2'-deoxycytidine; Chip, chromatin-immunoprecipitation; CKI, cyclin-dependent protein kinase inhibitor; FCS, fetal calf serum; HDAC, histone deacetylase; HL, Hodgkin's lymphoma; H/RS, Hodgkin and Reed-Sternberg; IR, ionizing radiation; LFS, LiFraumeni syndrome; MSP, methylation-specific PCR; PMSF, phenylmethyl sulfonyl fluoride; SB, sodium butyrate; TsA, trichostatin A

\section{Introduction}

Chk2, the mammalian homolog of the yeast Rad53 and Cds1 genes, encodes a nuclear serine/threonine kinase that plays a crucial role in the DNA damage response and helps guard the integrity of the genome by regulating cell-cycle checkpoints, DNA repair and apoptosis. ${ }^{1-3}$ Following DNA damage, Chk2 is phosphorylated and activated by ataxia-telangiectasiamutated (ATM)-dependent and -independent mechanisms, ${ }^{4-8}$ and exerts diverse biological effects via phosphorylation of its downstream effector molecules, including p53, Cdc25, BRCA1, PML and E2F-1. ${ }^{9-14}$ Importantly, germ-line mutations within the Chk2 gene have been reported in a subset of families with Li-Fraumeni syndrome (LFS), but who have a normal, wild-type $p 53,{ }^{15-17}$ suggesting that Chk2 may function as a tumor suppressor. While mutations in the Chk2 gene have been implicated in occasional sporadic tumors, ${ }^{3,18-22}$ somatic Chk2 mutations are rare in particular in lymphoid malignancies. ${ }^{23-25}$

Lymphoid malignancies are a heterogeneous group of neoplasms characterized by distinct clinical, immunophenotypical, morphological, cytological and genetic features. Alterations in tumor suppressors that are involved in the DNA damage response have been reported to be frequently involved in the pathogenesis of lymphoid malignancies. In particular, the incidence of $p 53$ mutations is apparently high in lymphoid malignancies, and is associated with the aggressive clinical development of these neoplasms. ${ }^{26,27}$ It has been reported that AT patients have a 100 -fold increased risk for the development of lymphoid malignancies. ${ }^{28}$ Furthermore, mutations in the ATM gene have been associated with the development of chromosomal instability in a subset of lymphoid malignancies as a result of impairment in the DNA damage response ${ }^{29,30}$ Since Chk2 acts downstream of ATM and upstream of p53, it is anticipated that mutations in Chk2 may also be involved in the onset or pathogenesis of lymphoid neoplasms.

In those infrequent cases where somatic Chk2 mutations do occur in sporadic tumors, including lymphoid malignancies, it has been found that nonsense or missense mutations often result in downregulated Chk2 expression or impaired kinase activity. ${ }^{20,31}$ It has also been recently reported that alterations in the post-transcriptional regulation of Chk2 expression occur 
in a subset of aggressive non-Hodgkin's lymphomas (HLs). ${ }^{32}$ In these cases, Chk2 protein is poorly expressed or absent, yet Chk2 mRNA is apparently expressed normally compared to other types of lymphomas, and no apparent mutation or altered methylation is found in the Chk2 gene. On the other hand, in $\mathrm{HL}$, malignant mononuclear Hodgkin and multinucleated Reed-Sternberg (H/RS) cells are occasionally found to harbor genetic and/or epigenetic alterations (e.g. mutation, splicing variants and DNA methylation) in genes encoding several cell-cycle regulators, including $\mathrm{p} 16^{\mathrm{INK} 4 \mathrm{a}}$, $\mathrm{p} 14^{\mathrm{ARF}}$ and $\mathrm{I}_{\kappa} \mathrm{B} \alpha{ }^{33-36}$ While p53 mutations are rather rare in $\mathrm{H} / \mathrm{RS}$ cells, ${ }^{37}$ the expression of genes or proteins involved in the DNA damage response in these cells has not been thoroughly examined.

Accumulating evidence demonstrates the importance of post-translational modification of histone proteins (i.e. acetylation, methylation and phosphorylation), in addition to DNA methylation, as epigenetic mechanisms involved in the organization of chromosomal domains and gene regulation. ${ }^{38-41}$ It is now generally appreciated that hyperacetylated histones $\mathrm{H} 3$ and $\mathrm{H} 4$ and methylated H3-lysine 4 are associated with activated genomic regions at both the local and global levels, while hypoacetylation of histones $\mathrm{H} 3, \mathrm{H} 4$ and methylation on $\mathrm{H} 3$-lysine 9 results in gene repression and silencing. Interestingly, it has been shown that there exists an interplay between DNA methylation and histone modification (methylation and acetylation). In fact, methylation of histone H3-lysine 9, associated with aberrant gene silencing of the p14ARF/p16INK4a locus in tumor cells, is rapidly reversed by treatment with a DNA methyltransferase inhibitor, 5-Aza-2'deoxycytidine $(5 \mathrm{Az}-\mathrm{dC}){ }^{42}$

In this study we first examined the expression levels of Chk2, p53 and Wip1 in nine cell lines from various lymphoid malignancies, including three HL lines. Chk2 mRNA and protein expression was dramatically lower in all three $\mathrm{HL}$ cell lines compared to the other cell lines, yet there was no apparent mutation in the Chk2 gene. Therefore, we tested the possibility that epigenetic mechanisms are involved in this aberrant expression of the Chk2 gene in these cells using the histone deacetylase (HDAC) inhibitors trichostatin A (TsA) and sodium butyrate (SB). Histone acetylation was assayed by a chromatin-immunoprecipitation (Chip) method. Our results indicate that decreased expression of the Chk2 gene in $\mathrm{HL}$ cells is due, at least in part, to hypoacetylation of histones $\mathrm{H} 3$ and $\mathrm{H} 4$. We further investigated the possible hypermethylation of the Chk2 gene in HL cells by DNA methylation assays, but found that the global methylation patterns in the Chk2 gene and the methylation status of a likely methylation site, a CpG-rich region upstream of the Chk2 gene, were unaffected in $\mathrm{HL}$ cells. However, treatment of $\mathrm{HL}$ cells with $5 \mathrm{Az}-\mathrm{dC}$ resulted in the hypomethylation of histone H3-lysine 9 and hyperacetylation of histones $\mathrm{H} 3$ and $\mathrm{H} 4$, leading the restoration of normal Chk2 expression. These findings indicate that DNA methylation of Chk2 at an as-yet unidentified site(s) is also involved in the downregulation of Chk2 expression, and that there exists an interplay between DNA methylation and histone modification in regulating the expression of Chk2 in HL cells. We also discuss the possible relationship between downregulation of Chk2 expression and the oncogenic properties of HL cells.

\section{Results}

\section{Expression of Chk2 mRNA and protein in cell lines from HLs and other lymphoid malignancies}

We first performed Northern blot analysis to examine the expression levels of Chk2, p53 and Wip1 mRNAs in nine cell lines from various lymphoid malignancies; HDLM2 and L428 (HLs, nodular sclerosis), KM-H2 (HL, mixed cellularity), KM3 (pre-B lymphocytic leukemia), RL (non-HL), FL318 and FL518 (follicular lymphomas), Black93 (Burkitt's lymphoma), and Jurkat ( $T$ cell leukemia) (see Materials and Methods). Although the expression patterns of the Chk2, p53 and Wip1 mRNAs were different among the various cell lines examined, each transcript was detected at the predicted size, with the exception of p53 mRNA in HDLM2 and Jurkat cells (Figure 1a). Interestingly, all the three $\mathrm{HL}$ cells, HDLM2, $\mathrm{L} 428$ and $\mathrm{KM}-\mathrm{H} 2$ cells, exhibited drastically decreased expression of Chk2 mRNA compared to the other six cell lines (Figure 1a). The Chk2 genes from HL cells (L428 and $\mathrm{KM}-\mathrm{H} 2$ cells) and from $\mathrm{KM} 3$ and $\mathrm{RL}$ cells were not found to possess any apparent mutations within their exons by sequence analyses (data not shown). These results suggest that the Chk2 mRNA is altered at the transcriptional or posttranscriptional level in HL cells.

Decreased expression of Chk2 mRNA in HL cells would presumably result in the decreased expression of Chk2 protein. To verify this possibility, Chk2 protein expression was analyzed by anti-Chk2 immunoblots of whole-cell lysates. As shown in Figure 1b, Chk2 protein expression levels correlate generally with Chk2 mRNA levels in the cell lines examined, and decreased expression of Chk2 protein was observed in all three $\mathrm{HL}$ cells compared to other cell lines. It is possible that downregulation of Chk2 expression may be

a

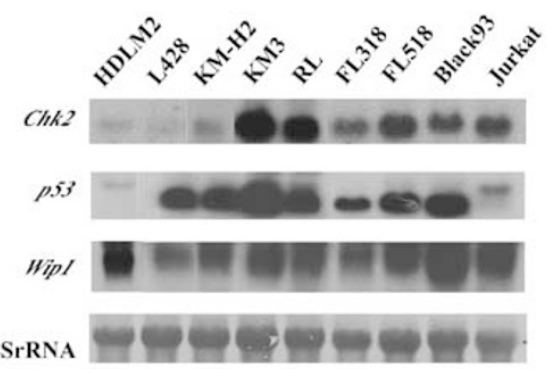

b

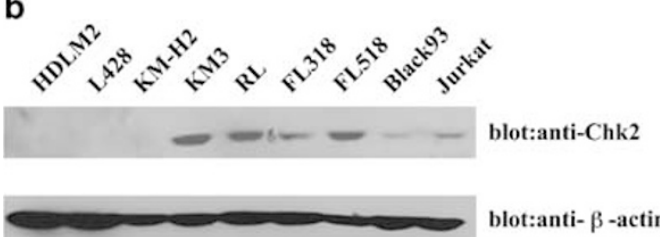

Figure 1 Expression levels of Chk2 mRNA and protein in cell lines from various malignancies. (a) Expression levels of Chk2, p53 and Wip1 mRNAs in the indicated cell lines derived from various lymphoid malignancies were determined by Northern blot analysis as described in Materials and Methods. Filters were stained with methylene blue to visualize $18 \mathrm{~S}$ and $28 \mathrm{~S}$ ribosomal RNAs (28SrRNA was indicated at the bottom panel). (b) Expression of Chk2 and $\beta$-actin proteins in the indicated cell lines was determined by anti-Chk2 or anti- $\beta$-actin immunoblotting of whole-cell lysates (equal protein amounts) from the respective cell lines as described in Materials and Methods 
involved in the resistance to apoptosis and the occurrence of aneuploidy frequently observed in HLs (see Discussion) ${ }^{36}$

\section{Effect of HDAC inhibitors (TsA and SB) on Chk2 expression in HL cells}

In order to clarify the mechanisms of altered Chk2 gene expression in $\mathrm{HL}$ cells, we tested the effect of the HDAC inhibitors TsA and SB on Chk2 expression in HL cells. HL cell lines (L428, KM-H2 and HDLM2 cells) and several other cell lines ( $K M 3$ and $R L$ cells) were treated with either TsA or SB for 2-3 days or left untreated, and the levels of Chk2, p53 and Wip1 mRNA expression were determined by Northern blot analysis. Intriguingly, treatment of $\mathrm{HL}$ cells with $\mathrm{SB}$ resulted in increased expression of Chk2 mRNA, but to levels lower than those observed in untreated KM3 and RL cells (Figure 1a and 2a, data not shown). Treatment of $\mathrm{L} 428$ and KM-H2, but not HDLM2 cells, with TsA also enhanced Chk2 expression to lesser extents compared to that with $\mathrm{SB}$, indicating differential sensitivities of the respective HL cells toward TsA and SB. The results are consistent with the idea that hypoacetylation of histones is responsible for the downregulation of Chk2 expression in $\mathrm{HL}$ cells. On the other hand, treatment of $\mathrm{HL}$ cells with TsA or SB caused a decrease in p53 and Wip1 mRNA (Figure 2a), indicating that some form of epigenetic regulation is ultimately responsible for $p 53$ and Wip1 expression in HL cells. These results suggest that aberrant gene expression of Chk2, p53 and Wip1 in $\mathrm{HL}$ cell lines is due, at least in part, to epigenetic regulation, that is, acetylation of histones.

We next examined expression of the Chk2 proteins in the three $\mathrm{HL}$ cell lines following treatment with TsA or SB (Figure $2 b$ ). Treatment of $\mathrm{L} 428$ and $\mathrm{KM}-\mathrm{H} 2$ cells with TsA or $\mathrm{SB}$ resulted in augmented expression of Chk2, as determined by immunoblot analysis (Figure $2 b$ ). Treatment of HDLM2 cells with SB, but not TsA, also caused an increase in Chk2 expression. Thus, in $\mathrm{HL}$ cell lines treated with these inhibitors, protein expression correlates with expression of each mRNA. This suggests that expression of these proteins is regulated, at least in part, by epigenetic mechanisms at the transcriptional level.

\section{Effect of DNA methyltransferase inhibitor 5Aza-dC on Chk2 expression in HL cells}

We next examined the effect of the DNA methyltransferase inhibitor 5Aza-dC on Chk2 expression (mRNA and protein) in $\mathrm{HL}$ cells (Figure $3 a$ ). To this end, HL cell lines (L428, KM-H2 and HDLM2 cells) were treated with 5 Aza-dC for 2-3 days or left untreated, and the levels of Chk2 mRNA and Chk2 protein were determined by Northern blot and immunoblot analyses, respectively. As shown in Figure $3 a$ (upper panel), treatment of $\mathrm{HL}$ cells with $5 \mathrm{Aza}-\mathrm{dC}$ resulted in increased expression of Chk2 mRNA, but to levels lower than those observed in untreated $K M 3$ and $R L$ cells (data not shown), suggesting that DNA methylation is also involved in the downregulation of Chk2 expression in HL cells. In agreement with Chk2 mRNA expression, treatment of $\mathrm{HL}$ cells with $5 \mathrm{Aza}-\mathrm{dC}$ also resulted in augmented expression of Chk2 protein, suggesting that

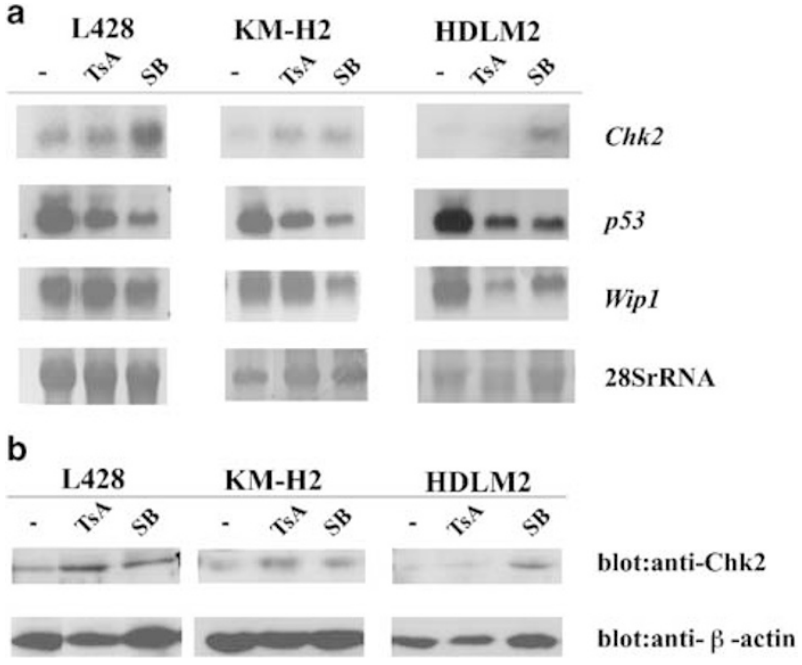

Figure 2 Expression of Chk2 mRNA and protein in $\mathrm{HL}$ cells (L428, KM-H2 and HDLM2) cells after treatment with TsA or SB. (a) HL cells (L428, KM-H2 and HDLM2 cells) were treated or not treated with TsA or SB for 2-3 days as described in Materials and Methods. Expression of Chk2, p53 and Wip1 mRNAs was determined by Northern blot analysis as described in Materials and Methods. Filters were stained with methylene blue to visualize $18 \mathrm{~S}$ and $28 \mathrm{~S}$ ribosomal RNAs (28SrRNA was indicated at the bottom panel). (b) HL cells (L428, KM-H2 and HDLM2 cells) were treated or not treated with TSA or SB for 2-3 days as described in Materials and Methods. Expression of Chk2 and $\beta$-actin proteins in the respective cells under the indicated conditions was determined by anti-Chk2 or anti- $\beta$-actin immunoblotting of whole-cell lysates (equal protein amounts) as described in Materials and Methods

expression of Chk2 protein is regulated, at least in part, by epigenetic mechanisms at the transcription level.

\section{Methylation status of Chk2 gene in HL and other malignant lymphoid cell lines}

The effects of 5Aza-dC on Chk2 gene expression in $\mathrm{HL}$ cell lines suggest that methylation of cytosine residues at $\mathrm{CpG}$ dinucleotides in the Chk2 gene may be involved in the regulation of Chk2 gene expression in these cells. To test this possibility, we examined overall methylation patterns in the Chk2 gene in $\mathrm{HL}$ (L428 and KM-H2 cells) and other cell lines (KM3 and RL cells). Genomic DNA from each cell line was digested with an isoschizomeric restriction enzyme pair; Hpall, which is methylcytosine-sensitive, and $\mathrm{Mspl}$, which is methylcytosine-resistant, or with Hindll as a control, and Southern blot analysis was performed as described in Materials and Methods. As expected, the genomic DNA from all the four cell lines digested with Mspl or Hindll exhibited identical band patterns, while that digested with Hpall exhibited a different pattern depending on the cell line (Figure $3 b$ ). It was also found that the overall methylation status of the Chk2 gene in $\mathrm{HL}$ and other cell lines does not correlate with the expression levels of Chk2 mRNA.

Database analysis revealed the presence of a CpG-rich region upstream of a putative transcription initiation site of Chk2 gene (Figure 3c). Therefore, we examined the methylation status within this CpG-rich region in L428 and KM3 cells using a methylation-specific PCR (MSP) method employing 


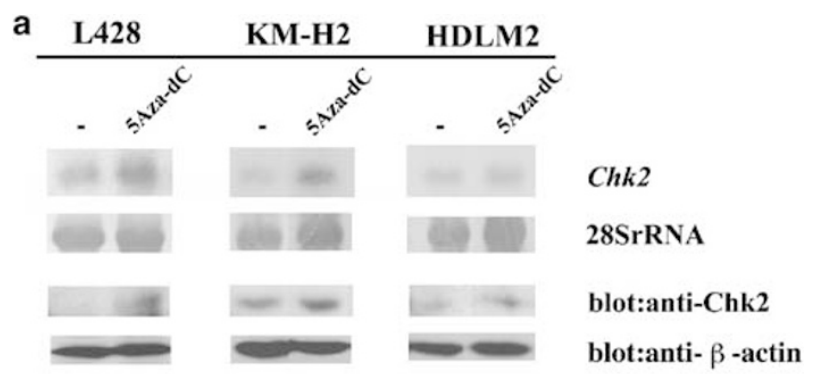

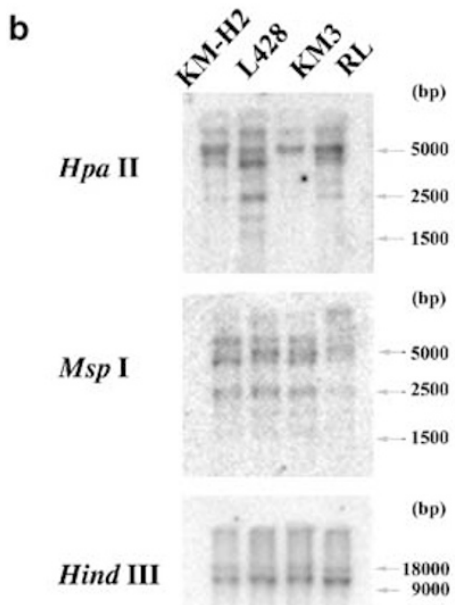

C

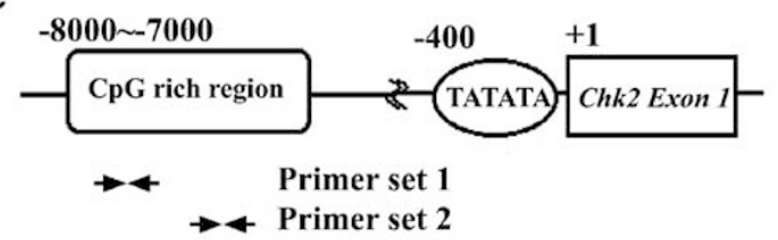

MSP analysis

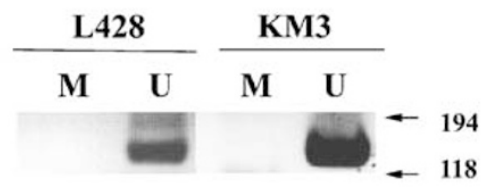

Figure 3 Methylation status of the Chk2 gene in HL cells. (a) HL cells (L428, $\mathrm{KM}-\mathrm{H} 2$ and HDLM2 cells) were treated or not treated with 5 Aza-dC for 2-3 days as described in Materials and Methods. Expression of Chk2 mRNA was determined by Northern blot analysis, and expression of Chk2 and $\beta$-actin proteins was determined by anti-Chk2 or anti- $\beta$-actin immunoblotting of wholecell lysates (equal protein amounts) as described in Materials and Methods. (b) Overall methylation pattern of the Chk2 gene was examined by Southern blot analysis using full-length cDNA probe for Chk2 as described in Materials and Methods. The molecular marker is shown to the right. (c) Methylation status within the $\mathrm{CpG}$-rich region of Chk2 gene was determined by MSP as described in Materials and Methods. Locations of the CpG-rich region and the MSP primer sets (primer sets 1 and 2) are indicated (upper panel). Bisulfite-treated DNAs from L428 and KM3 cells were amplified using two unmethylated (U) and methylated (M) DNA-specific primer sets. Amplification with the primer set $2(U$ and $\mathrm{M}$ ) is indicated (lower panel)

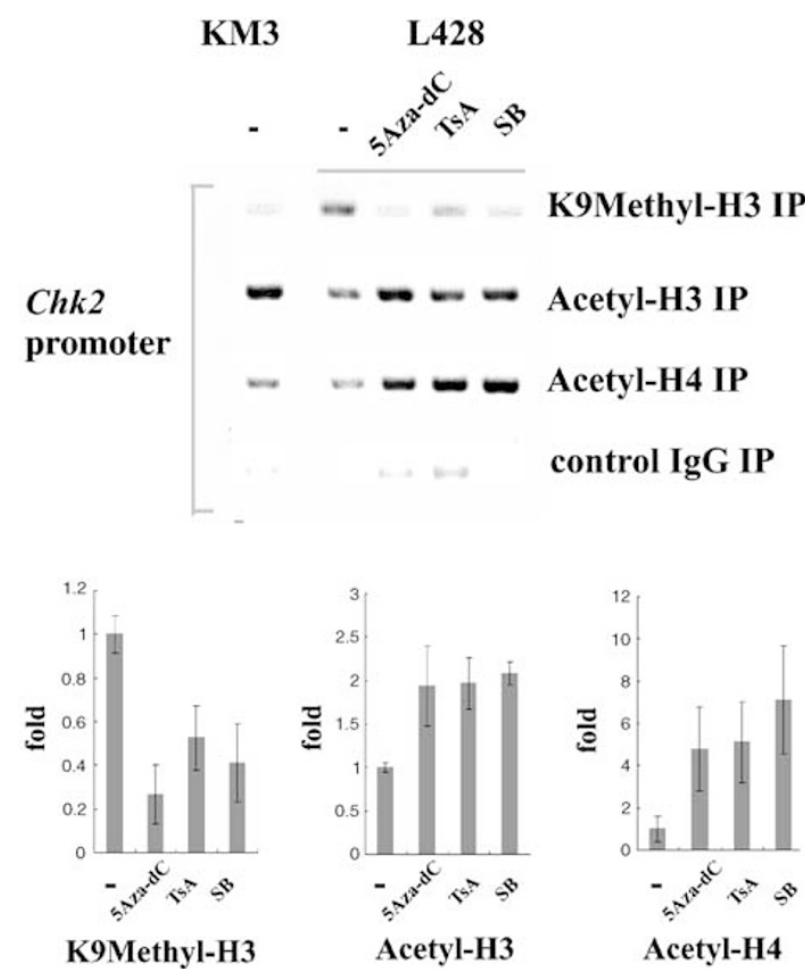

Figure 4 Levels of acetylated histone $\mathrm{H} 3$ and $\mathrm{H} 4$ and dimethylated histone $\mathrm{H} 3$ lysine 9 at the Chk2 promoter in L428 and KM3 cells after treatment with 5Aza$\mathrm{dC}$, TsA or SB. L428 and KM3 cells were treated with $5 \mathrm{Az}-\mathrm{dC}$, TsA, or SB or left untreated for 2-3 days as described in Materials and Methods. Chip was performed with antidimethyl histone $\mathrm{H} 3(\mathrm{~K} 9)$, antiacetyl histone $\mathrm{H} 3$, antiacetyl histone $\mathrm{H} 4$ or control antibodies, and the immunoprecipitated DNA was subjected to PCR with primers specific to the promoter region of the Chk2 gene as described in Materials and Methods. Chip PCR products were separated in $2 \%$ agarose gels, and stained with ethidium bromide. Histograms show quantitation of band intensity of the respective Chip PCR products (lower panel). Data are expressed as the mean \pm S.D. (relative to the levels in untreated cells $(-$, mock treated)) in four independent experiments

two MSP primer sets (primer sets 1 and 2) (Figure 3c). Genomic DNA from L428 and KM3 cells produced a strong PCR product with unmethylated sequence-specific primers, but not with the methylated sequence-specific primers (primer set 1). MSP analysis of the genomic DNA from both L428 and KM3 cells using primer sets 2 also amplified only the unmethylated sequence (data not shown). Thus, the CpGrich region of Chk2 in both L428 and KM3 cells appears to be unmethylated.

\section{Effect of 5Aza-dC TsA and SB on histone acetylation and methylation at the Chk2 promoter in $\mathrm{L} 428$ and $\mathrm{KM} 3$ cells}

To examine the acetylation status of the histones $\mathrm{H} 3$ and $\mathrm{H} 4$ associated with Chk2 gene, in particular the Chk2 promoter, in $\mathrm{HL}$ cells, we performed Chip using polyclonal antibodies against acetylated histone $\mathrm{H} 3$ and acetylated histone $\mathrm{H} 4$. We examined untreated KM3 cells, untreated $\mathrm{L} 428$ cells, and TsA- or SB-treated L428 cells as described in Materials and Methods. As shown in Figure 4, we observed that histone H3 
(and histone $\mathrm{H} 4$ ) associated with the Chk2 promoter was hypoacetylated in untreated $L 428$ cells compared to untreated KM3 cells. Treatment of L428 cells with either TsA or SB resulted in hyperacetylation of both histones $\mathrm{H} 3$ and $\mathrm{H} 4$, suggesting that decreased expression of the Chk2 gene in the $\mathrm{HL}$ cell line $\mathrm{L} 428$ is due, at least in part, to hypoacetylation of histones $\mathrm{H} 3$ and $\mathrm{H} 4$.

Since it has been shown that methylation of histone H3lysine (K) 9 is associated with inactive genes, we also examined the methylation status of this histone by Chip assay. Methylation of Chk2 promoter-associated H3-K9 was clearly higher in untreated $\mathrm{L} 428$ cells compared to untreated KM3 cells (Figure 4). This suggests that hypermethylation of histone H3-K9 may also be involved in repression of Chk2 gene expression in $\mathrm{L} 428$ cells. Accumulating evidence demonstrates an interplay between DNA methylation and histone modification (methylation and acetylation). ${ }^{42}$ The methyl-CpG binding protein, MeCP2, associates with HDAC complexes, suggesting a mechanism by which histone modification can be induced by changes in DNA methylation. ${ }^{43,44}$ Interestingly, treatment of L428 cells with 5 Aza-dC resulted in the drastic inhibition of histone $\mathrm{H} 3-\mathrm{K} 9$ methylation and enhancement of histones $\mathrm{H} 3$ and $\mathrm{H} 4$ acetylation, showing that there is indeed an interplay between DNA methylation and histone modification. Collectively, these results indicate the crucial role of epigenetic mechanisms in downregulating Chk2 gene expression in the HL cell line, L428 cells.

\section{Apoptotic changes induced by $\gamma$-irradiation in L428 cells by treatment with SB}

Recent studies have shown that $C h k 2^{-1-}$ mice and cells have decreased susceptibility to ionizing radiation (IR). ${ }^{45,46}$ It has also been reported that HL cells frequently exhibit resistance to apoptosis. ${ }^{36}$ Therefore, it is possible that the observed alteration in the expression of Chk2 and related genes in $\mathrm{HL}$ cells may be involved in apoptosis resistance. To examine this possibility, we examined the effect of SB on the susceptibility of $\mathrm{HL}$ cells ( $\mathrm{L} 428$ and KM-H2 cells) to apoptosis induced by $\gamma$ irradiation, as described in Materials and Methods. L428 cells were treated with SB, or left untreated, subjected to $\gamma$ irradiation (15 Gy), and labeled $24 \mathrm{~h}$ later with PI and annexin $\mathrm{V}$. Pl/annexin $\mathrm{V}$ dual staining indicated that the percentages of annexin $\mathrm{V}^{\text {high }} \mathrm{Pl}^{\text {high }}$ cells relative to total cells in untreated L428 cells increased from 4 to $14 \%$ in response to $\gamma$ irradiation, while the percentages in SB-treated L428 cells increased from 5 to $27 \%$ (Figure 5). Similar results were obtained when $\mathrm{KM}-\mathrm{H} 2$ cells were treated with $\mathrm{SB}$ (data not shown). These results imply that upregulation of Chk2 and other related genes in $\mathrm{HL}$ cells by SB treatment contributes to the increased susceptibility of $\mathrm{HL}$ cells to $\gamma$-irradiation.

\section{Discussion}

Chk2 kinase plays a central role in signaling in response to DNA damage, functioning downstream of ATM and upstream of p53. ${ }^{2,3}$ Following DNA damage, Chk2 is phosphorylated and activated by ATM-dependent and -independent mechanisms, ${ }^{4-8}$ and this activated Chk2 then phosphorylates and
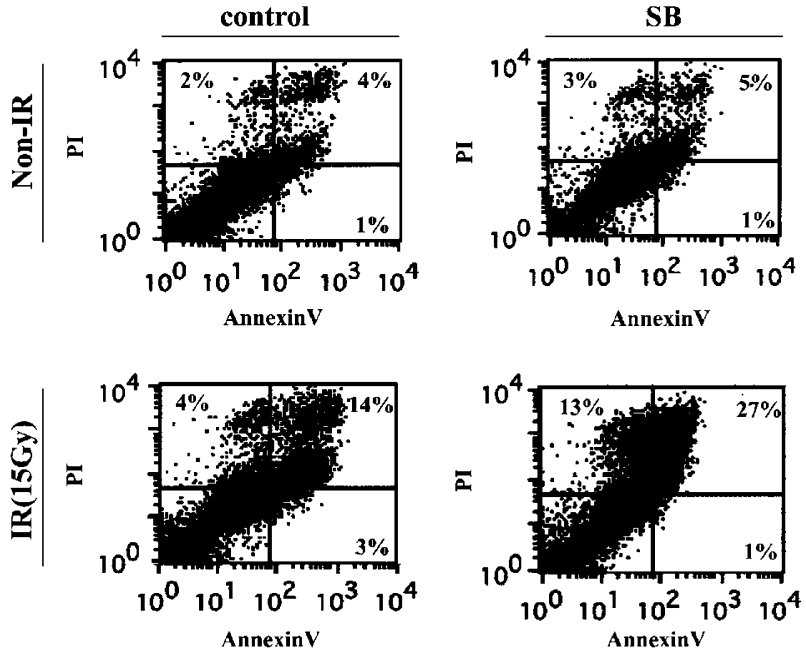

Figure 5 Detection of apoptotic changes induced by $\gamma$-irradiation in L428 cells treated with SB. L428 cells were treated with SB (final conc. $1 \mathrm{~mm}$ ) or left untreated for 2-3 days, subjected to $\gamma$-irradiation ( $15 \mathrm{~Gy}$ ), and subsequently cultured for $24 \mathrm{~h}$. Cells were labeled with FITC-conjugated annexin V mAB and $\mathrm{PI}$, and analyzed by flowcytometry as described in Materials and Methods. Numbers indicate percentages of annexin $\mathrm{V}^{\text {high }} \mathrm{PI}{ }^{\text {high }}$, annexin $\mathrm{V}^{\text {high }} \mathrm{PI}{ }^{\text {low }}$ and annexin $\mathrm{V}^{\text {low }} \mathrm{Pl}^{\text {high }}$ cells relative to total cells. Essentially identical results were obtained in two independent experiments

stabilizes p53. ${ }^{1-3,10,11}$ This, in turn, leads to induction of the p21 and Wip1 genes, which encode a cyclin-dependent protein kinase inhibitor (CKI) p21, and the oncogenic nuclear protein phosphatase Wip1, respectively. ${ }^{47-49}$ Interestingly, Wip1 has been shown to mediate negative feedback regulation of p38-p53 signaling in response to DNA damage. ${ }^{50}$ In addition, it has been well documented that most if not all molecules involved in DNA damage response signaling are tumor suppressors, and mutations of these genes have been implicated in a wide variety of tumors. In fact, germline mutations of the Chk2 gene have been identified in a subset of families affected by LFS, ${ }^{15-17}$ although somatic Chk2 mutations are rather rare, particularly in lymphoid malignancies. $^{23-25}$

In our present study, we found that cell lines from HLs exhibit drastically decreased expression of the Chk2, but not p53 and Wip1, compared to cell lines from other lymphoid malignancies. We found that this decreased expression was due, at least in part, to altered epigenetic regulation (Figures 1 and 2). In particular, downregulation of Chk2 gene expression was shown to involve hypoacetylation of histones $\mathrm{H} 3$ and $\mathrm{H} 4$, hypermethylation of histone H3-lysine (K) 9 and DNA hypomethylation at an as-yet-unidentified site(s) outside the CpG-rich region in the Chk2 promoter (Figures 3 and 4). Although a recent study has shown that aberrant posttranscriptional regulation of Chk2 expression may occur in a subset of aggressive non-HLs, ${ }^{32}$ we believe our data represent the first example of altered epigenetic regulation of Chk2 gene expression in cells from malignant tumors.

HLs are characterized by the presence of malignant mononuclear H/RS cells, surrounded by reactive cells attracted by cytokines and chemokines, which are abundantly 
produced by $H / R S$ cells. ${ }^{51}$ It has been reported that constitutive activation of nuclear factor (NF)- $\kappa \mathrm{B}$ and $\mathrm{AP}-1$ are also implicated in $\mathrm{HLs},{ }^{52-54}$ and that genetic and/or epigenetic alterations (e.g. mutation, splicing variant and DNA methylation) in genes encoding cell-cycle regulators, including $\mathrm{p} 16^{\mathrm{INK} 4 a}, \mathrm{p} 14^{\mathrm{ARF}}$ and $\mathrm{I} \kappa \mathrm{B} \alpha$, exist in $\mathrm{H} / \mathrm{RS}$ cells from HLs. ${ }^{33-36}$ Furthermore, a recent study using tissue-microarrays has revealed that Cyclin E, Cdk2, 6, Stat3, Hdm2, Bcl2, $\mathrm{Bcl}-\mathrm{XL}$, Survivin, molecules involved in cell-cycle regulation and prevention of apoptosis, are overexpressed in HLs, explaining their high proliferative activity and resistance to apoptosis. ${ }^{36}$ Intriguingly, polymorphic mutations of the ATM gene have recently been identified in childhood Hodgkin's disease. ${ }^{55}$ These mutated ATM genes encode functionally abnormal ATM proteins, suggesting the involvement of polymorphic variations of the ATM gene in the pathogenesis of childhood HD, presumably due to a defect in cell-cycle checkpoint regulation. Our findings, that altered epigenetic regulation of Chk2 gene in $\mathrm{HL}$ cells results in the downregulation of Chk2 kinase and abrogates DNA damage response signaling in the cells (Figure 5 , see below), suggest that this novel molecular feature of HLs that may also be useful for the diagnosis of the disease. In fact, downregulated expression of Chk2 and abrogation of DNA damage response could also account for the resistance to apoptosis and aneuploidy occasionally observed in HLs.

Our results demonstrate that downregulation of Chk2 gene expression in $\mathrm{HL}$ cell lines is due partly, if not entirely, to altered epigenetic regulation of the Chk2 gene, that is, hypoacetylation of histones $\mathrm{H} 3$ and $\mathrm{H} 4$, hypermethylation of H3-K9 and hypomethylation of DNA (Figures 2, 3a and 4). Although overall DNA methylation analysis of the Chk2 gene and MSP analysis of the CpG-rich region of Chk2 failed to detect a DNA methylation site(s) within the Chk2 gene that differs between HL and cells from other lymphoid malignancies (Figures $3 b$ and c), our results with 5Aza-dC (see Figures $3 a$ and 4) nevertheless indicate the involvement of DNA methylation in decreased Chk2 expression in HL cells. Further study will be required to identify potential crucial cytosine residues within the Chk2 gene. Our results with $5 \mathrm{Aza}-\mathrm{dC}$ also provide an example of the interplay between DNA methylation and histone modification (methylation and acetylation) ${ }^{42}$ (Figure 4). This interplay can be assumed to be mediated by a molecular mechanism whereby the methyl-CpG binding protein, MeCP2, associates with HDAC complexes. ${ }^{43,44}$ However, a recent study using a genetic approach has indicated that histone modification can occur independently of DNA methylation, and that DNA methylation serves to 'lock in', rather than initiate gene repression. ${ }^{56}$ Further study will be required to clarify this issue. Moreover, it has been appreciated that epigenetic regulation of gene expression can be affected by environment surrounding cells. Thus, the epigenetic regulation in particular cells in vitro and in vivo may be different. Since our present study is restricted to established $\mathrm{HL}$ cell lines, it will be of importance to examine the epigenetic regulation of the Chk2 gene by utilizing fresh specimens from patients with HLs.

It has been shown that targeted disruption of the Chk2 gene results in decreased susceptibility of cells in response to $\mathrm{IR}$, and that $\mathrm{HL}$ cells occasionally exhibit resistance to apoptosis. $^{36,45,46}$ Consistent with these observations, we found that upregulation of Chk2 in HL cells (L428 and KM$\mathrm{H} 2$ cells) following treatment by the HDAC inhibitor SB resulted in increased susceptibility of the cells to IR (Figure 5). At present we do not know to what extent SB-induced Chk2 expression contributes to this increased susceptibility. Future studies examining the effects of ectopically expressed Chk2 on the susceptibility to IR in $\mathrm{HL}$ cells might address this question. Importantly, our results may also provide some insight into the potential therapeutic use of HDAC inhibitors against malignant tumors, especially on the combined treatments (e.g. HDAC inhibitor and IR) for patients with HLs.

\section{Materials and Methods}

\section{Cell lines and culture conditions}

Three $\mathrm{HL}$ cell lines and six other lymphoid malignancies cell lines were analyzed. The $\mathrm{HL}$ cell lines were L428, HDLM2 (both nodular sclerosis), ${ }^{57}$ and $\mathrm{KM}-\mathrm{H} 2$ (mixed cellularity), ${ }^{57}$ and the other cell lines were KM3 (pre-B lymphocytic leukemia), ${ }^{58} \mathrm{RL}$ (non-HL), ${ }^{59} \mathrm{FL} 318$ and FL518 (follicular lymphomas), ${ }^{60}$ Black 93 (Burkitt's lymphoma), ${ }^{61}$ and Jurkat (T cell leukemia) ${ }^{62}$ All cell lines were maintained in RPMl1640 supplemented with $10 \%(\mathrm{v} / \mathrm{v})$ fetal calf serum (FCS). L428 cells were treated with 5 AzadC (5Aza-dC, Sigma) (final conc. $5 \mu \mathrm{M}$ ), TsA (Sigma) (final conc. $300 \mathrm{~nm}$ ), or SB (Aldrich) (final conc. $1 \mathrm{~mm}$ ) for 2-3 days.

\section{Northern blot analysis}

Cells were harvested and total RNA was prepared using the ISOGEN RNA preparation kit (Wako). Total RNA $(10 \mu \mathrm{g})$ was electrophoresed in $1 \%$ agarose formaldehyde gels and transferred onto nylon membranes (Nytran N, Schleicher \& Schuell) as described previously. ${ }^{63}$ Probes were labeled with $\left[\alpha^{-32} \mathrm{P}\right] \mathrm{dCTP}$ (Amersham, $3000 \mathrm{Ci} / \mathrm{mmol}$ ) using the Multiprimer labeling kit (Amersham) and were hybridized using PerfectHyb (TOYOBO) following the manufacturer's instructions. Specific activity was approximately $2 \times 10^{6} \mathrm{cpm} / \mathrm{ng}$ for each of the probe DNAs. $28 \mathrm{~S}$ rRNA was visualized by staining filters with methylene blue. The probe DNAs were prepared as follows: Chk2, ${ }^{1} 1.7 \mathrm{kbp}$ EcoRl-Xhol fragment from pcDNA3Chk2; $553,{ }^{64} 1.8 \mathrm{kbp} \mathrm{BamHI}$ fragment from pCMV-p53; Wip $1,{ }^{50} 1.8 \mathrm{kbp}$ Bgll-Sphl fragment from pCMV-Wip1.

\section{Southern blot analysis}

Genomic DNAs were prepared from the four cell lines ( $\mathrm{L} 428, \mathrm{KM}-\mathrm{H} 2, \mathrm{RL}$ and $\mathrm{KM} 3$ ) by phenol-chloroform extraction. To detect methylation sites within genomic DNA, genomic DNA $(10 \mu \mathrm{g})$ from each cell line was digested with Hpall (New England Biolabs) or Mspl (TAKARA). Both restriction enzymes recognize the same sequence 'CCGG', but Hpall cannot digest the methylated sequence, while Mspl can. ${ }^{65,66} \mathrm{Hpall}$ - or Mspl-digested DNAs were electrophoresed in 0.8\% agarose gels, and transferred onto nitrocellulose membranes (PROTRAN BA 85 CELLULOSENITRAT, Schleicher \& Schuell). Probes were labeled as described in Northern blot analysis. After hybridization, the membranes were washed with $5 \times \mathrm{SSC} / 0.1 \% \mathrm{SDS}$ at $65^{\circ} \mathrm{C}$.

\section{Methylation-specific PCR analysis}

To perform MSP ${ }^{67}$ genomic DNA $(2 \mu \mathrm{g})$ was treated with sodium bisulfite using the DNA Modification Kit (CpG Genome, Intergen), following the 
manufacturer's instructions. Bisulfite converts unmethylated cytosines, but not methylated cytosines, to uracil. The sequences of the MSP primers were as follows. Primer set 1: unmethylated DNA (U); $5^{\prime}$. GTTTTTTTTTTTTTGTAGGTTAGATTTTGAT- $3^{\prime}$ and $5^{\prime}$-CTTCAACCTTA TAAACTAATACAAACAACA-3'. methylated DNA (M); $5^{\prime}$-GTTTTT TTTTTTCGTAGGTTAGATTTCGAC-3' and $5^{\prime}$-CTTCAACCTTATAAAC TAATACGAACGACG-3'. Primer set 2: (U); 5'-TTGTTTGTGATGTAG TATTGTAGTTTAGTG-3' and 5'-ACAAATAACCACAACTAAATAAAC CACCAA-3'. (M); 5'-TCGTTTGCGACGTAGTATCGTAGTTAGCG-3' and $5^{\prime}$-ACGAATAACCACGACTAAATAAACCGCCGA-3'. The sequences recognized by these primers were located within a likely methylation site, a CpG-rich region upstream of the putative transcription initiation site of the Chk2 gene. Following PCR, the respective samples were fractionated on $2 \%$ agarose gels and visualized under UV.

\section{Protein preparation and immunoblotting}

Cells were harvested and solubilized with lysis buffer $(50 \mathrm{~mm}$ Tris- $\mathrm{HCl}(\mathrm{pH}$ 7.4), $0.5 \%$ (v/v) NP-40, $150 \mathrm{~mm} \mathrm{NaCl}, 5 \mathrm{~mm}$ EDTA, $50 \mathrm{~mm} \mathrm{NaF}, 1 \mathrm{~mm}$ $\mathrm{Na}_{3} \mathrm{VO}_{4}, 1 \mathrm{~mm}$ phenylmethyl sufhonyl fluoride (PMSF), $10 \mu \mathrm{g} / \mathrm{ml}$ leupeptin and $10 \mu \mathrm{g} / \mathrm{ml}$ aprotinin), and cell lysates were prepared by centrifugation at $12000 \times g$ for $15 \mathrm{~min}$ at $4^{\circ} \mathrm{C}$. Amounts of proteins in the respective cell lysates were quantitated by the Bio-Rad DC protein assay kit (Bio-Rad). Cell lysates containing equal amounts of proteins were separated by SDSPAGE (10\% PAG), and transferred onto PVDF membrane filters (Immobilon, Millipore). The membranes were immunoblotted with rabbit polyclonal anti-human Chk2 (HF, NK, TK, YM, unpublished data), anti-p53 (D01, Santa Cruz), or mouse monoclonal anti- $\beta$-actin (AC-15, SigmaAldrich) antibodies, and bound antibodies were visualized with HRPconjugated goat anti-rabbit IgG or goat anti-mouse IgG antibodies (BioRad) using a chemiluminescence reagent (Western Lightning, Perkin Elmer Life Sciences) following the manufacturer's instructions. Rabbit polyclonal anti-Chk2 antibody was raised against peptides corresponding to amino acids 523-543 of human Chk2.

\section{Chip assay}

In total, $1 \times 10^{6}$ cells were treated with $1 \%$ formaldehyde for $15 \mathrm{~min}$ at $37^{\circ} \mathrm{C}$ to crosslink proteins to DNA. Subsequently, chromatin was solubilized and subjected to sonication to obtain DNA fragments with an average size of 750-1000 bp. Chip assays were performed as described previously $^{68}$ with an equal amount $(5 \mu l)$ of antiacetyl histone $\mathrm{H} 3$, antiacetyl histone $\mathrm{H} 4$, antidimethyl histone $\mathrm{H} 3$ (K9) antibodies (Upstate Biotechnology) or normal rabbit IgG (Capel) as a control. The immunoprecipitated DNA was analyzed by PCR with primers specific to the Chk2 promoter region. The sequences of the primers utilized were $5^{\prime}$ GACGGAGTTTCACTATGTTGGCC-3' and 5'-CTGCCATGAGACTGCT GAGCCTCAACAT-3', respectively.

\section{Analysis of apoptosis}

Cells treated with or without SB were subjected to $\gamma$-irradiation (15 Gy) and cultured for $24 \mathrm{~h}$. Cells were harvested and labeled with annexin V and $\mathrm{PI}$ using the TACS Annexin V-Apoptosis Detection kit (R\&D systems) following the manufacturer's instructions and subsequently analyzed by a flow cytometry (FACSCalibur, Becton Dickinson). The percentages of cells in each fraction were analyzed using the software CellQuest.

\section{Acknowledgements}

We thank Drs. M Lamphier and A Noda for critical reading of the manuscript, E Tatsumi for providing HDLM2, KM-H2, L428, KM3, RL, FL318, FL518 and Black93 cells, A Kosugi for providing Jurkat cells and M Takao for encouraging this study. This work was supported in part by a Grant-in-Aid for Scientific Research on Priority Areas from the Ministry of Education, Culture, Sports, Science and Technology of Japan, the Yasuda Medical Research Foundation, the Cell Science Research Foundation, Nippon Boehringer Ingelheim, Co., Ltd, and Daiichi Pharmaceutical Co., Ltd.

\section{References}

1. Matsuoka S, Huang M and Elledge SJ (1998) Linkage of ATM to cell cycle regulation by the Chk2 protein kinase. Science 282: 1893-1897

2. Bartek J, Falck J and Lukas J (2001) Chk2 kinase - a busy messenger. Nat. Rev. Mol. Cell. Biol. 2: 877-886

3. Bartek J and Lukas J (2003) Chk1 and Chk2 kinases in checkpoint control and cancer. Cancer Cell 3: 421-429

4. Brown AL, Lee C-H, Schwarz JK, Mitiku N, Piwnica-Worms $\mathrm{H}$ and Chung JH (1999) A human Cds1-related kinase that functions downstream of ATM protein in the cellular response to DNA damage. Proc. Natl. Acad. Sci. USA 96: 3745-3750

5. Chaturvedi P, Eng WK, Zhu Y, Mattern MR, Mishra R, Hurle MR, Zhang X, Annan RS, Lu Q, Faucette LF, Scott GF, Li X, Carr SA, Johnson RK, Winkler JD and Zhou BB (1999) Mammalian Chk2 is a downstream effector of the ATMdependent DNA damage checkpoint pathway. Oncogene 18: 4047-4054

6. Melchionna R, Chen X-B, Blasina A and McGowan CH (2000) Threonine 68 is required for radiation-induced phosphorylation and activation of Cds1. Nat. Cell Biol. 2: 762-765

7. Matsuoka S, Rotman G, Ogawa A, Shiloh Y, Tamai K and Elledge SJ (2000) Ataxia telangiectasia-mutated phosphorylates Chk2 in vivo and in vitro. Proc. Natl. Acad. Sci. USA 97: 10389-10394

8. Ahn J-Y, Schwarz JK, Piwnica-Worms H and Canman CE (2000) Threonine 68 phosphorylation by ataxia telangiectasia mutated is required for efficient activation of Chk2 in response to ionizing radiation. Cancer Res. 60: 5934-5936

9. Blasina A, de Weyer IV, Laus MC, Luyten WH, Parker AE and McGowan $\mathrm{CH}$ (1999) A human homologue of the checkpoint kinase Cds1 directly inhibits Cdc25 phosphatase. Curr. Biol. 9: 1-10

10. Chehab NH, Malikzay A, Appel M and Halazonetis TD (2000) Chk2/hCds1 functions as a DNA damage checkpoint in $G_{1}$ by stabilizing p53. Genes Dev. 14: $278-288$

11. Shieh SY, Ahn J, Tamai K, Taya Y and Prives C (2000) The human homologs of checkpoint kinases Chk1 and Cds1 (Chk2) phosphorylate p53 at multiple DNA damage-inducible sites. Genes Dev. 14: 289-300

12. Lee JS, Collins KM, Brown AL, Lee CH and Chung JH (2000) hCds1-mediated phosphorylation of BRCA1 regulates the DNA damage response. Nature 404: 201-204

13. Yang S, Kuo C, Bisi JE and Kim MK (2002) PML-dependent apoptosis after DNA damage is regulated by the checkpoint kinase hCds1/Chk2. Nat. Cell Biol. 4: $865-870$

14. Stevens $C$, Smith $L$ and La Thangue NB (2003) Chk2 activates E2F-1 in response to DNA damage. Nat. Cell. Biol. 5: 401-409

15. Bell DW, Varley JM, Szydlo TE, Kang DH, Wahrer DC, Shannon KE, Lubratovich M, Verselis SJ, Isselbacher KJ, Fraumeni JF, Birch JM, Li FP, Garber JE and Haber DA (1999) Heterozygous germ line hChk2 mutations in Li-Fraumeni syndrome. Science 286: 2528-2531

16. Vahteristo $P$, Tamminen A, Karvinen $P$, Eerola $H$, Eklund $C$, Aaltonen LA, Blomqvist C, Aittomaki K and Nevanlinna H (2001) p53, Chk2, and Chk1 genes in Finnish families with Li-Fraumeni syndrome: further evidence of Chk2 in inherited cancer predisposition. Cancer Res. 61: 5718-5722

17. Lee SB, Kim SH, Bell DW, Wahrer DC, Schiripo TA, Jorczak MM, Sgroi DC, Garber JE, Li FP, Nichols KE, Varley JM, Godwin AK, Shannon KM, Harlow E 
and Haber DA (2001) Destabilization of CHK2 by a missense mutation associated with Li-Fraumeni syndrome. Cancer Res. 61: 8062-8067

18. Haruki N, Saito $\mathrm{H}$, Tatematsu $\mathrm{Y}$, Konishi $\mathrm{H}$, Harano $\mathrm{T}$, Masuda A, Osada $\mathrm{H}$, Fujii $Y$ and Takahashi T (2000) Histological type-selective, tumor-predominant expression of a novel $\mathrm{CHK} 1$ isoform and infrequent in vivo somatic $\mathrm{CHK} 2$ mutation in small cell lung cancer. Cancer Res. 60: 4689-4692

19. Bartkova J, Falck J, Rajpert-De Meyts E, Skakkebak NE, Lukas J and Bartek J (2001) Chk2 tumour suppressor protein in human spermatogenesis and testicular germ-cell tumours. Oncogene 20: 5897-5902

20. Matsuoka S, Nakagawa T, Masuda A, Haruki N, Elledge SJ and Takahashi T (2001) Reduced expression and impaired kinase activity of a Chk2 mutant identified in human lung cancer. Cancer Res. 61: 5362-5365

21. Miller CW, Ikezoe T, Krug U, Hofmann WK, Tavor S, Vegesna V, Tsukasaki K, Takeuchi S and Koeffler HP (2002) Mutations of the CHK2 gene are found in some osteosarcomas, but are rare in breast, lung, and ovarian tumors. Genes Chromosomes Cancer 33: 17-21

22. Reddy A, Yuille M, Sullivan A, Repellin C, Bell A, Tidy JA, Evans DJ, Farrell PJ, Gusterson B, Gasco M and Crook T (2002) Analysis of CHK2 in vulval neoplasia. Br. J. Cancer 86: 756-760

23. Hofmann WK, Miller CW, Tsukasaki K, Tavor S, Ikezoe T, Hoelzer D, Takeuchi $S$ and Koeffler HP (2001) Mutation analysis of the DNA-damage checkpoint gene Chk2 in myelodysplastic syndromes and acute myeloid leukemias. Leuk. Res. 25: 333-338

24. Tavor S, Takeuchi S, Tsukasaki K, Miller CW, Hofmann WK, Ikezoe T, Said JW and Koeffler HP (2001) Analysis of the CHK2 gene in lymphoid malignancies. Leuk. Lymphoma 42: 517-520

25. Hangaishi A, Ogawa S, Qiao Y, Wang L, Hosoya N, Yuji K, Imai Y, Takeuchi K, Miyawaki $\mathrm{S}$ and Hirai $\mathrm{H}$ (2002) Mutations of Chk2 in primary hematopoietic neoplasms. Blood. 99: 3075-3077

26. Imamura J, Miyoshi I and Koeffler HP (1994) p53 in hematologic malignancies. Blood 84: 2412-2421

27. Hernandez L, Fest T, Cazorla M, Teruya-Feldstein J, Bosch F, Peinado MA, Piris MA, Montserrat E, Cardesa A, Jaffe ES, Campo E and Raffold M (1996) p53 gene mutations and protein overexpression are associated with aggressive variants of mantle cell lymphomas. Blood 87: 3351-3359

28. Morrell D, Cromartie E and Swift M (1986) Mortality and cancer incidence in 263 patients with ataxia telangiectasia. J. Natl. Cancer Inst. 77: 89-92

29. Camacho E, Hernandez L, Hernandez S, Tort F, Bellosillo B, Bea S, Bosch F, Montserrat E, Cardesa A, Fernandez PL and Campo E (2002) ATM gene inactivation in mantle cell lymphoma mainly occur by truncating mutations and missense mutations involving the phosphatidylinositol-3 kinase domain and is associated with increasing numbers of chromosomal imbalances. Blood 99: 238-244

30. Stankovic T, Stewart GS, Fegan C, Biggs P, Last J, Byrd PJ, Keenan RD, Moss PA and Taylor AM (2002) Ataxia telangiectasia mutated-deficient B-cell chronic lymphocytic leukemia occurs in pregerminal center cells and results in defective damage response and unrepaired chromosome damage. Blood 99: 300-309

31. Wu X, Webster SR and Chen J (2001) Characterization of tumor-associated Chk2 mutations. J. Biol. Chem. 276: 2971-2974

32. Tort F, Hernandez S, Bea S, Martinez A, Esteller M, Herman JG, Puig X, Camacho E, Sanchez M, Nayach I, Lopez-Guillermo A, Fernandez PL, Colomer D, Hernandez L and Campo E (2002) CHK2-decreased protein expression and infrequent genetic alterations mainly occur in aggressive types of non-Hodgkin lymphomas. Blood 100: 4602-4608

33. Garcia JF, Villuendas R, Sanchez-Beato M, Sanchez-Aguilera A, Sanchez L, Prieto I and Piris MA (2002) Nucleolar p14 (ARF) overexpression in ReedSternberg cells in Hodgkin's lymphoma: absence of p14 (ARF)/Hdm2 complexes is associated with expression of alternatively spliced Hdm2 transcripts. Am. J. Pathol. 160: 569-578

34. Garcia JF, Villuendas R, Algara P, Saez Al, Sanchez-Verde L, MartinezMontero JC, Martinez P and Piris MA (1999) Loss of p16 protein expression associated with methylation of the p16INK4A gene is a frequent finding in Hodgkin's disease. Lab. Invest. 79: 1453-1459

35. Jungnickel B, Staratschek-Jox A, Brauninger A, Spieker T, Wolf J, Diehl V, Hansmann ML, Rajewsky K and Kuppers R (2000) Clonal deleterious mutations in the IkappaBalpha gene in the malignant cells in Hodgkin's lymphoma. J. Exp. Med. 191: 395-402

36. Garcia JF, Camacho FI, Morente M, Fraga M, Montalban C, Alvaro T, Bellas C, Castano A, Diez A, Flores T, Martin C, Martinez MA, Mazorra F, Menarguez J,
Mestre MJ, Mollejo M, Saez Al, Sanchez L, Piris MA and Spanish Hodgkin Lymphoma Study Group (2003) Hodgkin and Reed-Sternberg cells harbor alterations in the major tumor suppressor pathways and cell-cycle checkpoints: analyses using tissue microarrays. Blood 101: 681-689

37. Maggio EM, Stekelenburg E, Van den Berg A and Poppema S (2001) TP53 gene mutations in Hodgkin lymphoma are infrequent and not associated with absence of Epstein-Barr virus. Int. J. Cancer 94: 60-66

38. Nakayama J-I, Rice JC, Strahl BD, Allis CD and Grewal SIS (2001) Role of histone $\mathrm{H} 3$ lysine 9 methylation in epigenetic control of heterochromatin assembly. Science 292: 110-113

39. Turner BM (2002) Cellular memory and the histone code. Cell 111: 285-291

40. lizuka M and Smith MM (2003) Functional consequences of histone modifications. Curr. Opin. Genet. Dev. 13: 154-160

41. Fischle $W$, Wang $Y$ and Allis $C D(2003)$ Histone and chromatin cross-talk. Curr. Opin. Cell Biol. 15: 172-183

42. Nguyen CT, Weisenberger DJ, Velicescu M, Gonzales FA, Lin JC, Liang G and Jones PA (2002) Histone H3-Lysine 9 methylation is associated with aberrant gene silencing in cancer cells and is rapidly reversed by 5 -Aza-2' deoxycytidine. Cancer Res. 62: 6456-6461

43. Nan X, Ng HH, Johnson CA, Laherty CD, Turner BM, Eisenman RN and Bird A (1998) Transcriptional repression by the methyl-CpG-binding protein MeCP2 involves a histone deacetylase complex. Nature 393: 386-389

44. Jones PL, Veenstra GJ, Wade PA, Vermaak D, Kass SU, Landsberger N, Strouboulis J and Wolffe AP (1998) Methylated DNA and MeCP2 recruit histone deacetylase to repress transcription. Nat. Genet. 19: 187-191

45. Hirao A, Cheung A, Duncan G, Girard PM, Elia AJ, Wakeham A, Okada H, Sarkissian T, Wong JA, Sakai T, De Stanchina E, Bristow RG, Suda T, Lowe SW, Jeggo PA, Elledge SJ and Mak TW (2002) Chk2 is a tumor suppressor that regulates apoptosis in both an ataxia telangiectasia mutated (ATM)dependent and an ATM-independent manner. Mol. Cell. Biol. 22 6521-6532

46. Takai H, Naka K, Okada Y, Watanabe M, Harada N, Saito S, Anderson CW, Appella E, Nakanishi M, Suzuki H, Nagashima K, Sawa H, Ikeda K and Motoyama N (2002) Chk2-deficient mice exhibit radioresistance and defective p53-mediated transcription. EMBO J. 21: 5195-5205

47. Fiscella M, Zhang H, Fan S, Sakaguchi K, Shen S, Mercer WE, Vande Woude GF, O'Connor PM and Appella E (1997) Wip1, a novel human protein phosphatase that is induced in response to ionizing radiation in a p53dependent manner. Proc. Natl. Acad. Sci. USA 94: 6048-6053

48. Harper JW, Adami GR, Wei N, Keyomarsi K and Elledge SJ (1993) The p21 Cdk-interacting protein Cip1 is a potent inhibitor of cyclin-dependent kinases. Cell 19: 805-816

49. El-Deiry WS, Tokino T, Velculescu VE, Levy DB, Parsons R, Trent JM, Lin D, Mercer WE, Kinzler KW and Vogelstein B (1993) WAF1, a potential mediator of p53 tumor suppression. Cell 19: 817-825

50. Takekawa M, Adachi M, Nakahata A, Nakayama I, Itoh F, Tsukuda H, Taya Y and Imai K (2000) p53-inducible Wip1 phosphatase mediates a negative feedback regulation of p38 MAPK-p53 signaling in response to UV radiation. EMBO J. 19: 6517-6526

51. Yung $L$ and Linch $D$ (2003) Hodgkin's lymphoma. Lancet 361: 943-951

52. Hinz M, Löser P, Mathas S, Krappmann D, Dörken B and Scheidereit C (2001) Constitutive NF- $\kappa$ B maintains high expression of a characteristic gene network, including CD40, CD86, and a set of antiapoptotic genes in Hodgkin/ReedSternberg cells. Blood 97: 2798-2807

53. Mathas S, Hinz M, Anagnostopoulos I, Krappmann D, Lietz A, Jundt $F$, Bommert K, Mechta-Grigoriou F, Stein H, Dorken B and Scheidereit C (2002) Aberrantly expressed c-Jun and JunB are a hallmark of Hodgkin lymphoma cells, stimulate proliferation and synergize with NF- $\kappa$ B. EMBO J. 21: 4104-4113

54. Hinz M, Lemke P, Anagnostopoulos I, Hacker C, Krappmann D, Mathas S, Dorken B, Zenke M, Stein H and Scheidereit C (2002) Nuclear factor $\kappa$ Bdependent gene expression profiling of Hodgkin's disease tumor cells, pathogenetic significance, and link to constitutive signal transducer and activator of transcription 5a activity. J. Exp. Med. 196: 605-617

55. Takagi M, Tsuchida R, Oguchi K, Shigeta T, Nakada S, Shimizu K, Ohki M, Delia D, Chessa L, Taya Y, Nakanishi M, Tsunematsu Y, Bessho F, Isoyama K, Hayashi Y, Kudo K, Okamura J and Mizutani S (2004) Identification and characterization of polymorphic variations of the ataxia telangiectasia mutated (ATM) gene in childhood Hodgkin disease. Blood 103: 283-290 
56. Bachman KE, Park BH, Rhee I, Rajagopalan H, Herman JG, Baylin SB, Kinzler KW and Vogelstein B (2003) Histone modifications and silencing prior to DNA methylation of a tumor suppressor gene. Cancer Cell 3: 89-95

57. Hsu SM, Zhao X, Chakraborty S, Liu YF, Whang-Peng J, Lok MS and Fukuhara $S$ (1988) Reed-Sternberg cells in Hodgkin's cell Lines HDLM, L428, and KM-H2 are not actively replicating: lack of bromodeoxyuridine uptake by multinuclear cells in culture. Blood 71: 1382-1389

58. Nakamura M, Kudo T, Narimatsu H, Furukawa Y, Kikuchi J, Asakura S, Yang W, Iwase S, Hatake K and Miura Y (1998) Single glycosyltransferase, core $2 \beta 1$ to 6- $\mathrm{N}$-acetylglucosaminyltransferase, regulates cell surface Sialy-Lex expression level in human pre-B lymphocytic leukemia cell line KM3 treated with phorbolester. J. Biol. Chem. 273: 26779-26789

59. Beckwith M, Longo DL, O'Connell CD, Moratz CM and Urba WJ (1990) Phorbol ester-induced, cell-cycle-specific, growth inhibition of human B-lymphoma cell lines. J.Natl. Cancer Inst. 82: 501-509

60. Amakawa R, Fukuhara S, Ohno H, Tanabe S, Horii M, Matsuyama F, Kato I, Kakita T and Nagauchi O (1990) Amplified and rearranged bcl-2 gene in two lymphoma cell lines, FL-218 and FL-318, carrying a 14;18 translocation. Cancer Res. 50: 2423-2428

61. Tani A, Tatsumi E, Nakamura F, Kumagai S, Kosaka Y, Sano K, Nakamura H, Amakawa R and Ohno H (1996) Sensitivity to dexamethasone and absence of bcl-2 protein in Burkitt's lymphoma cell line (Black 93) derived from a patient with acute tumor lysis syndrome: comparative study with other $B L$ and non-BL lines. Leukemia 10: 1592-1603

62. Weiss A, Wiskocil RL and Stobo JD (1984) The role of T3 surface molecules in the activation of human T cells: a two-stimulus requirement for
IL 2 production reflects events occurring at a pre-translational level. J. Immunol. 133: $123-128$

63. Oishi I, Iwai K, Kagohashi Y, Fujimoto H, Kariya K, Kataoka T, Sawa H, Okano $\mathrm{H}$, Otani H, Yamamura H and Minami Y (2001) Critical role of Caenorhabditis elegans homologs of Cds1 (Chk2)-related kinases in meiotic recombination. Mol. Cell. Biol. 21: 1329-1335

64. Baker SJ, Markowitz S, Fearon ER, Willson JK and Vogelstein B (1990) Suppression of human colorectal carcinoma cell growth by wild-type p53. Science 249: 912-915

65. Roman-Gomez J, Castillejo JA, Jimenez A, Gonzalez MG, Moreno F, Rodriguez Mdel C, Barrios M, Maldonado J and Torres A (2002) $5^{\prime} \mathrm{CpG}$ island hypermethylation is associated with transcriptional silencing of the p21CIP1/ WAF1/SDI1gene and confers poor prognosis in acute lymphoblastic leukemia. Blood 99: 2291-2296

66. Kawano S, Miller CW, Gombart AF, Bartram CR, Matsuo Y, Asou H, Sakashita A, Said J, Tatsumi E and Koeffler HP (1999) Loss of p73 gene expression in leukemias/lymphomas due to hypermethylation. Blood 94: 1113-1120

67. Herman JG, Graff JR, Myohanen S, Nelkin BD and Baylin SB (1996) Methylation-specific PCR: a novel assay for methylation status of $\mathrm{CpG}$ islands. Proc. Natl. Acad. Sci. USA 93: 9821-9826

68. Ghoshal K, Datta J, Majumder S, Bai S, Dong X, Parthun M and Jacob ST (2002) Inhibitors of histone deacethylase and DNA methyltransferase synergistically active the methylated metallothionein I promoter by activating the transcription factor MTF-1 and forming an open chromatin structure. Mol. Cell. Biol. 22: 8302-8319 